\title{
PARASITIC FAUNA OF SARDINELLA AURITA VALENCIENNES, 1847 FROM ALGERIAN COAST
}

\author{
Souhila Ramdani ${ }^{a^{*}}$, Jean-Paul Trilles ${ }^{\mathrm{b}}$ and Zouhir Ramdane ${ }^{\mathrm{a}}$
}

\author{
a'Laboratoire de la zoologie appliquée et de l'écophysiologie animale, université Abderrahmane Mira-Bejaia, Algérie; \\ bUniversité de Montpellier, 34000 Montpellier, France \\ *Corresponding author. Email: sousane.green@gmail.com
}

\author{
Article history \\ Received: 10 May 2020; \\ accepted 18 August 2020
}

Keywords:

Parasites; Clupeidae fish;

Gulf of Bejaia

\begin{abstract}
The parasitic fauna of Sardinella aurita Valenciennes, 1847 from the Gulf of Bejaia (eastern coast of Algeria) was studied. The parasites collected from 400 host fish specimens, comprised 10 taxa including 6 species of Digenea, 1 species of Copepoda, 1 species of Nematoda, 1 larva of Cestoda and an unidentified Microsporidian species. The Nematoda Hysterothylacium sp. and the Copepoda Clavellisa emarginata (Krøyer, 1873) are newly reported for S. aurita. The Digenean parasites were numerous, diverse and constituted the most dominant group $(\mathrm{P}=33.63 \%)$. The checklist of all known parasite species collected from $S$. aurita in the Mediterranean Sea includes 13 species, among which eight are Digeneans.
\end{abstract}

\section{INTRODUCTION}

Sardinella aurita Valenciennes, 1847 , is a small widely distributed pelagic fish. It frequently occurs along the Algerian coastline as well as in Tunisia, Egypt, Greece and Sicily (Dieuzeide and Roland 1957; Kartas and Quignard 1976). The biology of S. aurita has been studied in the Mediterranean Sea by many researchers (Bounhioul 1921; Dieuzeide and Roland 1957; Chavance et al. 1985; Bouaziz et al. 2001; Hamida 2003; Bouaziz 2007). However, its parasitic fauna was investigated rarely (Derbel et al. 2012; Feki et al. 2015; Mansour et al. 2016), particularly along the Algerian coast. Taking into consideration the high economic importance of this fish, it is vital to know about its parasitic fauna. Pathogenic parasites induce diseases and may cause losses in the economic value of their hosts.

Microsporidia, for example, are among important protozoan parasites affecting fish (Dykova et al. 1980), in which they are transmitted both horizontally and vertically (MacNeil et al. 2003; Haine et al. 2004) and cause pathologies ranging from extensive muscle degeneration (Slothouber-Galbreath et al. 2004) to changes in the sex-ratio (Haine et al. 2007; Mautner et al. 2007). Microsporidia are common parasites of fish from different geographical areas (Caffara et al. 2010; Jithendran et al. 2011; Morsy et al. 2013; Abdel-Baki et al. 2015; Mansour et al. 2016; Frenette et al. 2016; Jones et al. 2017; Ovcharenko et al. 2017). The study of Microsporidia inducing xenomas in fish offers an insight into cell pathology. It is of interest since many of these species are important agents of fish diseases (Dykova 1995; Shaw et al. 1999). They have economic consequences and negative impacts when they cause disease in commercially valuable fish (Yokoyama et al. 2002; Kent et al. 2014; Phelps et al. 2015; Mansour et al. 2016).

The aim of this study was to identify the parasitic fauna infecting S. aurita from the eastern coast of Algeria, and to establish a checklist of all known parasite species infecting $S$. aurita from the Mediterranean Sea.

\section{MATERIALS AND METHODS}

During the period from October 2017 to October 2018, 400 specimens of $S$. aurita were collected from the Gulf of Bejaia (eastern coast of Algeria) and examined for parasites. The number of examined fish by age, size classes and months is indicated in Table 1.

The fish caught by local fishermen were transported to the laboratory immediately after landing. All parts of the body of each fish were carefully examined for attached parasites by both naked eye and with a binocular magnifying glass. Lesions and external changes were noted. For each fish specimen, the following parameters were recorded: total length (TL) in $\mathrm{cm}$ using an ichthyometer, total mass $(\mathrm{Wt})$ and mass of gutted fish (We) in $\mathrm{g}$ using a precision balance (precision $=$ $0.1 \mathrm{~g}$ ). Subsequently, the sex was determined. Once the parasites had been collected, they were cleaned and immediately preserved in pure ethanol (protozoan) and then transferred to $70 \%$ ethanol (for subsequent identification). Digenea and Cestoda (larvae) were stained, dehydrated in a graded series of ethanol dilutions $\left(70^{\circ}\right.$, $85^{\circ}, 95^{\circ}$ and $100^{\circ}$ ), cleared in clove oil and mounted in Canada balsam. Parasitic copepods were later cleared 
Table 1. Number of examined fish specimens per months, size classes and age.

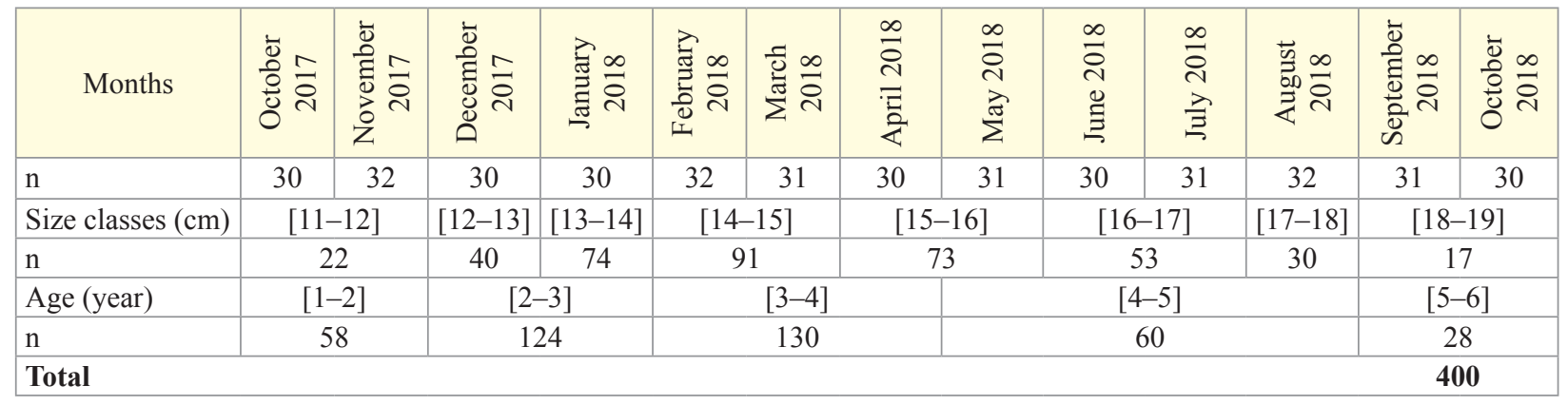

n: number of examined fishes.

Table 2. Parasitogical indexes according to parasites species infecting Sardinella aurita.

\begin{tabular}{|l|c|c|c|c|c|}
\hline \multicolumn{1}{|c|}{ Digenea } & 33.63 & 1.18 & 0.39 & & \\
\hline Aphanurus stossichii (Monticelli, 1891)* & 9.73 & 1.36 & 0.13 & DT & E \\
\hline Parahemiurus merus (Linton, 1910)* & 5.31 & 1.25 & 0.06 & DT & E \\
\hline Derogenes latus Janiszewska, 1953* & 0.44 & 1 & 0.004 & DT & E \\
\hline Lecithochirium sp.* $^{*}$ Hemiurus communis Odhner, 1905* & 1.76 & 4 & 0.004 & DT & E \\
\hline Hemiurinea sp.* & 0.44 & 1 & 0.004 & DT & E \\
\hline Cestoda & 15.49 & 1.2 & 0.18 & DT & E \\
\hline Tetraphyllidea larvea sp.* & 0.88 & 0.5 & 0.004 & & \\
\hline Copepoda & 0.88 & 0.5 & 0.004 & DT & E \\
\hline Clavellisa emarginata (Krøyer, 1873)* & 13.27 & 2.03 & 0.27 & & \\
\hline Nematoda & 13.27 & 2.03 & 0.27 & Gi & E \\
\hline Hysterothylacium sp.* ${ }^{*}$ & 0.88 & 1.5 & 0.013 & & \\
\hline Protozoan & 0.88 & 1.5 & 0.013 & PC & E \\
\hline Unidentified Microsporidian* & 23.45 & 1 & 0.226 & & PC/DT \\
\hline
\end{tabular}

P\%: Prevalence (\%); Im: Mean intensity; A: Mean abundance; M: Microhabitat; H/S: Host specificity; DT: Digestive tract; PC: Peritoneal cavity; Gi: Gills; E: Euryxenic; *: Newly collected parasites on S. aurita from the east coast of Algeria.

in $85 \%$ lactic acid for 1 to $2 \mathrm{~h}$ before dissection. The parasites were identified using identification keys based on their morpho-anatomic characteristics.

To evaluate parasitism, we calculated three parasitological indices (Bush et al. 1997):

1. Prevalence $(\mathrm{P} \%)=$ the number of hosts infested (n) / the number of fish specimens examined $(\mathrm{H})$ $\times 100$.

2. Mean intensity $(\operatorname{Im})=$ the number of parasite specimens (n) / the number of infested hosts.

3. Age, estimated using otholithometry.

To examine protozoan parasites, the xenoma was crushed, and three types of smears were prepared: (fresh, fixed and stained). Fresh spores were observed using an optical microscope, and the diameter of the spores was measured using an ocular micrometer. The smears were left to dry in ambient temperature. After drying, the smears were stained with Giemsa and HaematoxylinEosin (H\&E).

\section{RESULTS}

\section{Diversity of the collected parasites}

The ten parasite taxa observed for the first time on Sardinella aurita Valenciennes, 1847 from the eastern coast of Algeria are as follows: Digenea, Aphanurus stossichii (Monticelli 1891), Parahemiurus merus (Linton 1910), Derogenes latus Janiszewska, 1953, Lecithochirium sp., Hemiurinae sp. and Hemiurus communis Odhner 1905, Copepoda, Clavellisa emarginata (Krøyer 1873), Nematoda, Hysterothylacium sp., Cestoda, Tetraphylidea larvae and an unidentified Microsporidian (Table 2).

The fish specimens infected with Microsporidia did not show any external alteration in their appearance in contrast to infections with other parasite taxa; no external morphological signs of disease were recorded. Macroscopically, the infection manifested itself in numerous visible xenomas in the general cavity of the host fish S. aurita (Figure 1A, white arrows). These xenomas are easy to extract from the organs to which 
they are attached. The xenomas observed in infected fish varied in number ( 1 to 6 ) and in diameter $(6 \mathrm{~mm}$ to 15 $\mathrm{mm})$. Also, they differed in appearance, consistency and color. The vast majority of xenomas were found in the peritoneal cavity and were either i) rigid- and irregularshaped with a hard chalky exterior containing a solid, crumbly, cream-coloured, dark yellowish substance free of any liquid; or of regular spherical shape with a highly flexible wall containing a white liquid. The microscopic examination of fresh wet smears, Giemsa stained smears, and smears stained with HematoxylinEosin (H\&E), prepared from the contents of the crushed xenomas, revealed a large number of mature ovoid- to
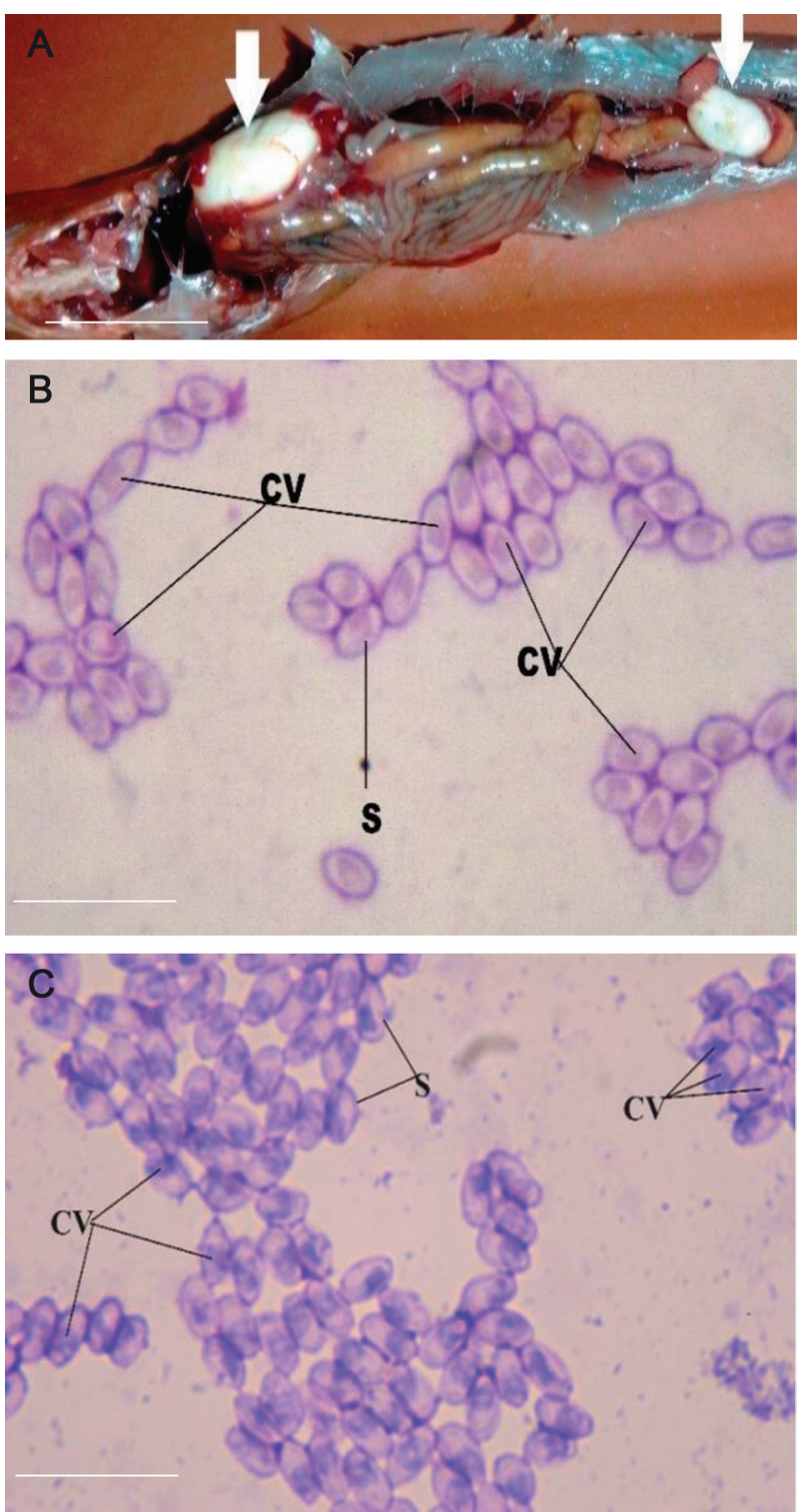

Figure 1. A, Xenomas attached to the general cavity of Sardinella aurita (white arrows); Scale bar: $2 \mathrm{~cm}$. An unidentified microsporidian observed in fresh wet smears and fixed smears stained with Haematoxylin-Eosin and with Giemsa; B, a large number of spores in a thin smear (Haematoxylin-Eosin staining $\times 100)$. Scale bar: $0.2 \mu \mathrm{m}$; $\mathrm{C}$, a large number of spores in a thin smear (Giemsa stain $\times 100$ ). Scale bar: $0.2 \mu \mathrm{m}$. S: spores, $\mathrm{CV}$ : central vacuole. ellipse-shaped spores (Figure 1B, C). Each spore contained a large central vacuole occupying more than half of the spore volume (Figure 1C). The nematodes Hysterothylacium sp. and Clavellisa emarginata (Krøyer 1873) are newly reported from S. aurita. Our results (Table 2) show that $S$. aurita hosts an abundance of diverse parasite species, especially metazoan parasites. Generally, the parasites collected from S. aurita show euryxenic specificity to their host.

\section{Infection rates}

The Digenea is the most diversified group (6 species) of metazoan parasites and the most represented in the metazoan parasite fauna of $S$. aurita $(\mathrm{P}=33.6 \%$ and $\mathrm{Im}$ $=1.18$ parasites per infected host) (Table 2).

The highest infection rates were recorded for Hemiurinea sp. $(\mathrm{P}=15.5 \%)$, Clavellisa emarginata $(\mathrm{P}=13.3 \%)$, Aphanurus stossichii $(\mathrm{P}=9.7 \%)$ and Parahemiurus merus $(\mathrm{P}=5.31 \%)$. According to our results, Lecithochirium sp. and Clavellisa emarginata show the highest mean intensity (respectively 4 and 2.03 parasites per infected host). The remaining parasite species have relatively low prevalence ranging from $0.4 \%$ to $1.8 \%$ (Table 2 ). Parasite attachment sites are variable, with the digestive tract (Digenea, Cestoda, Nematoda), the peritoneal cavity (Microsporidian) followed by the gills, which is a favourable environment for Copepoda, being the most common. The prevalence of infection with protozoan parasites is relatively the highest $(\mathrm{P}=23.5 \%)$ (Table 2$)$.

The identified parasites infect $S$. aurita throughout the year, the highest prevalence (more than $60 \%$ ) being observed in summer (June and July particularly) and spring (March) (Figure 2C). All size classes of S. aurita are parasitized (Figure 2B), and especially size classes $11-12 \mathrm{~cm}$ and $18-19 \mathrm{~cm}$. The most infected specimens are those older than 5 years $(\mathrm{P}=75.0 \%$; $\mathrm{Im}=1-2$ parasite per infected host) (Figure 2A). Younger specimens (1-2 years) are less infected $(\mathrm{P}=4.5 \% ; \mathrm{Im}=1$ parasites per infected host) (Figure 2A). Ours results show that male specimens were more infected $(\mathrm{P}=62.4 \%)$ than the female ones $(\mathrm{P}=54.9 \%)$.

The overall prevalence of Microsporidia was relatively significant $(\mathrm{P}=23.5 \%)$. Our observations reveal that the specimens with the total length (TL) of 11-12 cm were the most infected with Microsporidian parasites.

\section{DISCUSSION}

In this study, the parasitic fauna of Sardinella aurita was newly recorded off the Algerian coast. The following ten parasite taxa were collected: Aphanurus stossichii, Parahemiurus merus, Derogenes latus, Lecithochirium sp., Hemiurinae sp., Hemiurus communis, Clavellisa 

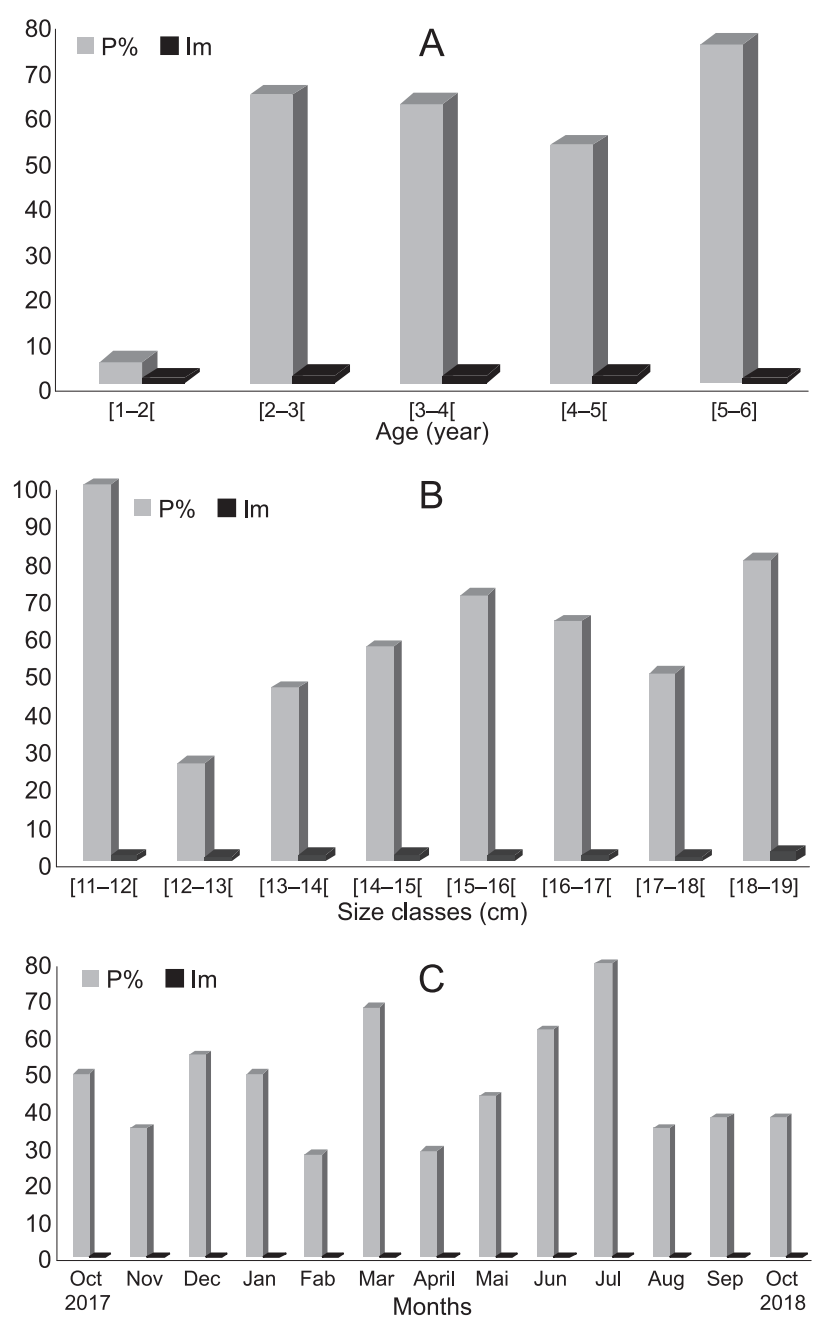

Figure 2. Parasitogical indexes according to age (A), size class (B) and month (C).

emarginata, Hysterothylacium sp., Tetraphylidea larvae and an unidentified Microsporidian (molecular study will be required for species identification). Thirteen nominal parasite species of this host species are well known from their previous records from different localities in the Atlantic-Mediterranean region (Bartoli et al. 2000; Derbel et al. 2012; Feki et al. 2015 and the present study). The majority of the parasite species we identified had previously been reported from $S$. aurita off the coast of Tunisia (Derbel et al. 2012; Feki et al. 2015), and from other fish species caught in different localities (the Atlantic-Mediterranean region and the Black Sea) (Bartoli et al. 2000, 2005; Mackenzie et al. 2008; Merzoug et al. 2012; Ichalal et al. 2015; Öztürk and Özer 2016; Ider et al. 2018). The parasitic fauna of $S$. aurita is diverse and the Digeneans are well represented. Our results corroborate those reported by Derbel et al. (2012) and Feki et al. (2015).

The unidentified Microsporidian reported in this paper is its first record off the Algerian coastline. Its taxonomic position should be subject to further investigation using phylogenetic data. A microsporidian (Glugea sardinellensis) was reported by Mansour et al. (2016) from the
Tunisian coast. Among the species identified from $S$. aurita, Hemiurinae sp.; Aphanurus stossichii, Tetraphylidea larvae were previously recorded by Ider et al. (2018) in Boops boops caught off the Algerian coast, Hemiurus communis and Aphanurus stossichii were reported by Ichalal et al. (2015) from Trachurus trachurus caught along the Algerian coastline. The parasites Parahemiurus merus and Aphanurus stossichii were identified by Merzoug et al. (2012) from Sardina pilchardus collected from the west coast of Algeria. The parasite Derogenes latus was recorded by Bartoli and Gibson (1991) in Mullus surmuletus captured in the western Mediterranean Sea. Clavellisa emarginata, recorded here, is newly reported along the northeastern coastline of Algeria. We collected one species of nematode Hysterothylacium sp. from $S$. aurita, which is a previously unknown host of this parasite. It is very important to update the inventory of the parasitic fauna infesting $S$. aurita because parasites have often been used as biological markers for discrimination among different stocks of $S$. aurita (Feki et al. 2015) in fish population studies (Mackenzie 2002; Mackenzie and Abaunza 2005) and for investigations of fish migratory movements (Oliva 2001). Our parasite indices show that rates of $S$. aurita infestation with all identified parasite species are relatively low, with the highest abundance of Hemiuridea sp. $(\mathrm{P}=15.5 \%)$ and Clavellisa emarginata $(\mathrm{P}=13.3 \%)$ being recorded. Our results do not corroborate those of Derbel et al. (2012), who reported a predominance of Aphanurus stossichii and Parahemiurus merus in the same host species. The infection rate was observed to vary according to months, which means that the seasonal timing of sampling is important.

The highest prevalence of parasites was recorded from March to July inclusive (2018). This result can be explained by an increase in water temperature, which may favour the population growth of parasites as has been observed for Digenean parasites. The same results were reported by De Kinkelin (1971). Ramdane et al. (2013) found that warm seasons clearly enhance parasitism in the specimens of Boops boops and Mullus barbatus barbatus caught in the coastal waters of Algeria. Ichalal et al. (2015) and Ider et al. (2018) recorded the highest infestation rates of Trachurus trachurus and Boops boops in spring. Microhabitat varies according to parasite species, while the digestive tract and gills were reported by Ichalal et al. (2015) and Ider et al. (2018) to be sites with the highest infestation rates. Increasing prevalence from April to July can be explained by a high abundance of prey species, i.e. intermediate hosts (zooplankton especially copepods) on which S. aurita feeds (Fedekar 2012). The phase of constant infestation rate observed from August to October might be related to low prey abundance. As reported by Bahar and Tuncay (2015), the emptiest stomachs of $S$. aurita from the Mediterranean Sea (in the Turkish Aegean) were encountered during autumn. Ichalal et 
al. (2015), Ider et al. (2018) and Saadi et al. (2020) have shown that the trophic behavior of fishes can increase the likelihood of infection with parasites, especially with those infesting crustacean and molluscan hosts.

Planktivorous fishes exhibiting pelagic behavior become infected with Digeneans and parasitic nematode larvae through ingestion of their intermediate hosts such as euphausiids, and copepods (Ichalal et al. 2015; Smith 1983). In addition, intensive infestation of $S$. aurita in April-July precedes its first reproductive period, which occurs from July to October (Palomera and Sabatès 1990). Many authors (Abattouy et al. 2011; Eissa et al. 2018) have reported that the highest prevalence of infection with Helminths was recorded in summer. As for ectoparasites, warm water in spring and summer enhances proliferation of infective forms with consequent rises in infection rates.

The highest infection rates were observed in older and larger individuals, with Digeneans being the dominant parasite group. This result can be explained by $S$. aurita feeding habits. Juveniles of this species feed on phytoplankton comprising a large quantity of diatoms (Fedekar 2012). However, adults feed on many species (groups) of zooplankton such as Copepods, Mollusks, Siphonophores, Teleostean eggs and larvae, Polychaeta, Chaetognatha and Tunicate (Lomiri et al. 2008; Fedekar 2012; Bahar and Tuncay 2015). Most of these species constitute potential prey (intermediate hosts) for parasites, especially for those with a complex life cycle like Digeneans. Pérez-del Olmo et al. (2007) linked the predominance of Digenea to the proliferation of intermediate hosts and the increase in copepod biomass. Small (1-2-year-old) fish have a low prevalence of infection. The rapid increase in infection observed in 2-3-year-old and older specimens may be explained by changes in $S$. aurita feeding behavior, i.e. shift towards larger prey (Crustaceans, Mollusks, etc.), which facilitates infection with Digeneans, and Nematodes. Three-year-old fish move to nurseries, facilitating their infection (endemiotopes) with mesoparasites and ectoparasites through feeding and contact (lateral transfer) respectively.

Abattouy et al. (2011) and Ichalal et al. (2015) reported

Table 3. Checklist of parasites collected from the Mediterranean on Sardinella aurita.

\begin{tabular}{|c|c|c|}
\hline Parasites species & Studied area & References \\
\hline \multicolumn{3}{|l|}{ Digenea } \\
\hline \multirow[t]{2}{*}{ Lecithochirium sp. } & Tunisia & Derbel et al. 2012; Feki et al. 2015 \\
\hline & Algeria & Present study \\
\hline \multirow[t]{2}{*}{ Parahemiurus merus (Linton, 1910) } & Tunisia & Derbel et al. 2012; Feki et al. 2015 \\
\hline & Algeria & Present study \\
\hline \multirow[t]{2}{*}{ Aphanurus stossichii (Monticelli, 1891) } & Tunisia, Greece, Spain & $\begin{array}{l}\text { Derbel et al. 2012; Feki et al. 2015; Sofronios and } \\
\text { Papoutsoglou 1975; Lozano et al. } 2001\end{array}$ \\
\hline & Algeria & Present study \\
\hline Derogenes latus Janiszewska, 1953 & Algeria & Present study \\
\hline Monorchis monorchis (Stossich, 1890) & Greece & Sofronios and Papoutsoglou 1975 \\
\hline Bacciger bacciger (Rudolphi, 1819) & Greece & Sofronios and Papoutsoglou 1975 \\
\hline Hemiurus appendiculatus (Rudolphi, 1802) & Greece & Sofronios and Papoutsoglou 1975 \\
\hline Hemiurus communis Odhner, 1905 & Algeria & Present study \\
\hline Lecithaster confusus Odhner, 1905 & Greece & Sofronios and Papoutsoglou 1975 \\
\hline Hemiurinea sp. & Algeria & Present study \\
\hline \multicolumn{3}{|l|}{ Monogena } \\
\hline Mazocraes sp. & Tunisia & Feki et al. 2015 \\
\hline \multicolumn{3}{|l|}{ Cestoda } \\
\hline \multirow[t]{2}{*}{ Tetraphyllidean larva } & Tunisia & Feki et al. 2015 \\
\hline & Algeria & Present study \\
\hline Calliobothrium sp. & Greece & Sofronios and Papoutsoglou 1975 \\
\hline \multicolumn{3}{|l|}{ Copepoda } \\
\hline Mitrapus oblongus (Pillai, 1964) & Egypt, Turkey & El-Rashidy and Boxshall 2009; Romero and Öktener 2010 \\
\hline Clavellisa ilishae Pillai, 1962 & Egypt & El-Rashidy and Boxshall 2009 \\
\hline Clavellisa emarginata (Krøyer, 1873) & Algeria & Present study \\
\hline \multicolumn{3}{|l|}{ Nematoda } \\
\hline Anisakis pegreffii & Italy & Piras et al. 2014 \\
\hline Hysterothylacium sp. & Algeria & Present study \\
\hline \multicolumn{3}{|l|}{ Protozoa } \\
\hline Glugea sardinellensis (Thélohan, 1892) & Tunisia & Mansour et al. 2016 \\
\hline Eimerias ardinae (Thélohan, 1890) & Yugoslavia & Daoudi et al. 1989 \\
\hline Unidentified Microsporidian & Algeria & Present study \\
\hline
\end{tabular}


size-dependent infection rates in teleost hosts from the Mediterranean coasts of Morocco and Algeria. They postulated that intermediate prey, i.e. intermediate hosts of these parasites, constitute a significant part in the diet of large fish, which increases infection rates.

In summary, the rates of infection we recorded in $S$. aurita could be related to numerous factors: temperature, prey availability, host behavior, food availability, feeding behavior and reproductive physiology.

In this study, male specimens were found to be more infected $(\mathrm{P}=62.4 \%)$ than females $(\mathrm{P}=54.9 \%)$. Our results show that the number of parasites is related to sex, which is in agreement with the findings reported by Tantanasi et al. (2012) and Ichalal et al. (2015). This result corroborates those reported by Mansour et al. (2016), who recorded high infection $(P=70.0 \%)$ with Glugea sardinellensis $(11-13 \mathrm{~cm})$ in small fish specimens. Host fish pick up Microsporidian parasites through the ingestion of free spores from the water column (Weissenberg 1968). Intestinal infection with microsporidia in S. aurita off the coast of Tunisia was first reported by Mansour et al. (2016). A molecular study should be conducted in order to identify this Microsporidian to the species level.

The checklist confirms that $S$. aurita is infected with numerous and various parasite species (Table 3). Until now, $S$. aurita from the Mediterranean Sea has been known to get infected with 21 parasite taxa (protozoan and metazoan parasites). Digenea were the most represented parasite group ( 8 species). The groups of parasites collected by the authors were represented by only 2-3 taxa (Table 3 ).

$S$. aurita from the Algerian coast is infected with 10 parasite taxa (9 metazoan and 1 protozoan). S. aurita from the coastal waters of Algeria was not found to be infected with monogeneans, but it was found to be infected with 6 Digenean species. As for the other parasitic taxa that we have identified, each of them was represented by only 1 parasite species (Table 3 ).

\section{ACKNOWLEDGMENTS}

We warmly thank the fishermen who helped us in our sampling survey. We also thank the anonymous reviewers for their remarks and corrections.

\section{REFERENCES}

Abattouy, N., A. Valero, M. H. Benajiba, J. Lozano, and J. Martín-Sánchez. 2011. Anisakis simplex s. 1. parasitization in mackerel (Scomber japonicus) caught in the
North of Morocco - Prevalence and analysis of risk factors. International Journal of Food Microbiology 150: 136-139.

Abdel-Baki, A. S., F. T. Ahmad, H. A. Al-Qahtani, S. AlQuraishy, and L. Mansour. 2015. Glugea jazanensis sp. nov. infecting Lutjanus boharin the Red Sea: ultrastructure and phylogeny. Diseases of aquatic organisms 116 : 185-190. doi: 10.3354/dao02927

Bahar, B., and M. S. Tuncay. 2015. Feeding of the round sardinella Sardinella aurita Valenciennes, 1847 (Osteichthyes: Clupeidae) in the Turkish Aegean Sea. International Journal of Fauna and Biological Studies 2 (4): 38-42.

Bartoli, P., and D. I. Gibson. 1991. On Podocotyle scorpaenae, Poracanthium furcatum and Derogenes latus, three poorly known digenean parasites of western Mediterranean teleosts. Systematic parasitology 20: 29-46. doi. org/10.1007/BF00009709

Bartoli, P., D. I. Gibson, and R. A. Bray. 2005. Digenean species diversity in teleost fish from a nature reserve off Corsica, France (western Mediterranean), and a comparison with other Mediterranean regions. Journal of Natural history 39 (1): 47-70.

Bartoli, P., O. Jousson, and F. Russell-Pinto. 2000. The life cycle of Monorchis parvus (Digenea: Monorchiidae) demonstrated by developmental and molecular data. Journal of Parasitology 86: 479-489.

Bouaziz, A. 2007. La sardinelle (Sardinella aurita, Valencienne, 1847) des côtes algériennes, distribution, biologie et estimation des biomasses [The sardinella (Sardinella aurita, Valencienne, 1847) of the Algerian coasts, distribution, biology and estimation of biomasses]. Thèse de doctorat d'état, u.s.t.hb, 135 pp.

Bouaziz, A., A. Bennoui, B. Brahmi, and R. Semroud. 2001. Sur l'estimation de l'état d'exploitation de la sardinelle (Sardinella aurita Valenciennes, 1847) de la région centre de la cote algérienne [On the estimation of the state of exploitation of the sardinella (Sardinella aurita Valenciennes, 1847) of the central region of the Algerian coast]. Rapp. comm. int. mer medit. 36: 244.

Bounhioul, J. P. 1921. Sur la biologie de l'allache (Sardinella aurita valenc.) des côtes d'Algérie [On the biology of the allache (Sardinella aurita valenc.) of the coasts of Algeria]. Rapp presente au congrès de Strasbourg de l'assoc. franc. avanc. sci.: 1920.

Bush,A. O., K. D. Lafferty, J. M. Lotz, and A.W. Shostak. 1997. Parasitology meets ecology on its own terms: Margolis et al. revisited. Journal of Parasitology 83: 575-583.

Caffara, M., F. Quaglio, F. Marcer, D. Florio, and M. L. Fioravanti. 2010. Intestinal microsporidiosis in European seabass (Dicentrarchus labrax L.) Farmed in Italy. Bulletin of European Association of Fish Pathology 30 (6): 237.

Chavance, P., F. Chabane, F. Hemida, H. S. Korichi, M. P. Sanchez, G. L. Bouchereau, G. A. Tomasini, and 
F. Djabali. 1985. Evaluation du rendement par recrue relatif à partir de fréquences de tailles: application a quelques stocks d'anchois, de sardinelles et de chinchards de la méditerranée occidentale [Evaluation of relative yield per recruit from size frequencies: application to some anchovy, sardinella and horse mackerel stocks in the western Mediterranean]. Fao rapp. Pèche 347: 186-220.

De Kinkelin, P. 1971. Précis de pathologie des poissons [Precis of fish pathology]. Paris: Masson Institut national de la recherche agronomique, $487 \mathrm{pp}$.

Derbel, H., M. Chaari, and L. Neifar. 2012. Digenean species diversity in teleost fishes from the gulf of Gabes. Tunisia (western Mediterranean). Parasites 19: 129-135.

Dieuzeide, R., and J. Roland. 1957. Étude biométrique de Sardina pilchardus walb.et de Sardinella aurita c.v., capturées dans la baie de Castiglione [Biometric study of Sardina pilchardus walb. and Sardinella aurita c.v., captured in the Bay of Castiglione]. Bulletin sta. aquic. Pêche Castiglione (8) : 111-216.

Dykova, I. 1995. Phylum microspora. In Fish diseases and disorders, protozoan and metazoan infections, edited by Woo, P. T. K., 1: 149-179. Cambridge, UK: Cab International.

Dykova, I., J. Lom, and S. Egusa. 1980. Tissue reaction to Glugea plecoglossi infection in its natural host, Plecoglossus altevelis. Folia parasitologica (Praha) 27: 213-216.

Eissa, A. E., M. D. L. Showehdi, M. M. Ismail, A. S. ElNaas, A. A. Abu Mhara, and S. K. Abolghait. 2018. Identification and prevalence of Anisakis pegreffii and A. pegreffi $-A$. simplex (s. s.) hybrid genotype larvae in Atlantic horse Mackerel (Trachurus trachurus) from some North African Mediterranean coasts. Egyptian Journal of Aquatic Research 44: 21-27.

Fedekar, F. M. 2012. Feeding ecology of the round sardinella, Sardinella aurita (Family: Clupeidae) in the Egyptian Mediterranean waters. International Journal of Environmental Science and Engineering (IJESE) 2: 83-92.

Feki, M., M. Chaari, and L. Neifar. 2015. Spatial variability of helminth parasites and evidence for stock discrimination in the round sardinella, Sardinella aurita (Valenciennes, 1847), off the coast of Tunisia. Journal of helminthology 90: 353-358.

Frenette, A. P., E. Matthias, H. Haakon, D. B. Michael, I. Burta, and S. D. Michael. 2016. Integrative approach for the reliable detection and specific identification of the microsporidium Loma morhua in Atlantic cod (Gadus morhua). Journal of eukaryotic microbiology 64 (1): 67-77.

Haine, E. R., E. Brondani, K. D. Hume, M. J. Perrot-Minnot, M. Gaillard, and T. Rigaud. 2004. Coexistence of three Microsporidia parasites in populations of the freshwater amphipod Gammarus roeseli: evidence for vertical transmission and positive effect on reproduction. International journal for parasitology 34: 1137-1146.

Haine, E. R., S. Motreuil, and T. Rigaud. 2007. Infection by a vertically-transmitted Microsporidian parasite is associated with a female-biased sex ratio and survival advantage in the amphipod Gammarus roeseli. Parasitology 134: 1363-1367.

Hamida, C. 2003. Biologie et dynamique de la sardinelle: Sardinella aurita (Valenciennes, 1847) dans le golfe de Annaba. [Biology and dynamics of the sardinella Sardinella aurita Valenciennes, 1847) in the Gulf of Annaba]. Mémoire de magistère univers. Badji Mokhtar. ann.fac. sciences. dept. Sciences de la mer. lab. Bioressources Marines (biomares), $67 \mathrm{pp}$.

Ichalal, K., Z. Ramdane, D. Ider, M. Kacher, M. Iguerouada, J. P. Trilles, L. Courcot, and R. Amara. 2015. Nematodes parasitizing Trachurus trachurus (L.) and Boops boops (L.) from Algeria. Parasitology Research 114: 4059-4068. doi 10.1007/s00436-015-4633-6.

Ider, D., Z. Ramdane, J. P. Trilles, and R. Amara. 2018. Metazoan parasites of Boops boops (Linnaeus, 1758) from the Algerian coast. Cah. Biol. Mar.: 59.

Jithendran, K. P., K. K. Vijayan, and M. Kailasam. 2011. Microsporidian (Glugea sp.) infection in the greasy grouper Epinephelus tauvina (Forsskal, 1775). Indian journal of fishery 58 (3): 125-127.

Jones, S. R., H. S. Ahonen, L. Granlund, T. Arsiol, and J. Taskinen. 2017. Two novel microsporidia in skeletal muscle of pike-perch Sander lucioperca and Burbot Lota lota in Finland. American society of parasitologists. Journal of Parasitology 103 (1): 95-102.

Kartas, F., and J. P. Quignard. 1976. Contribution a' l'étude de l'allache (Sardinella aurita Val., 1847) des côtes de Libye. [Contribution to the study of the sardinella (Sardinella aurita Val., 1847) of the Libyan coasts]. Rapp. comm. int. mer me' dit. 23: 33-34.

Kent, M. L., R. W. Shaw, and J. L. Sanders. 2014. Microsporidia in fish. In Microsporidia pathogens of opportunity, edited by L. M. Weiss, and J. J. Becnel, 493-520. Ames, Iowa: Wiley Blackwell.

Lomiri, S., U. Scacco, E. Mostarda, and F. Andaloro. 2008. Size-related and temporal variation in the diet of the round sardinella, Sardinella aurita (Valenciennes, 1847), in the central Mediterranean Sea. Journal of Applied Ichthyology 24: 539-545.

Mackenzie, K. 2002. Parasites as biological tags in population studies of marine organisms: an update. Parasitology 124: 153-163.

Mackenzie, K., and P. Abaunza. 2005. Parasites as biological tags. In Stock identification methods. Applications in fisheries science, edited by Cadrin, S. X., K. D. Friedland, and J. R. Waldman, 211-226. San Diego, USA: Elsevier academic press.

Mackenzie, K., N. Campbell, S. Mattiuccii, P. Ramos, A. I. Pinto, and P. Abaunza. 2008. Parasites as biological tags 
for stock identification of Atlantic horse mackerel Trachurus trachurus L. Fishery Research 89: 136-145.

MacNeil, C., J. T. A. Dick, M. J. Hatcher, N. J. Fielding, K. D. Hume, and A. M. Dunn. 2003. Parasite transmission and cannibalism in an amphipod (Crustacea). International journal for parasitology 33: 795-798.

Mansour, L., A. Thabet, A. A. Harrath, S. Y. Al Omar, A. Mukhtar, S. R. Sayed, and A. S. Abdel-Baki. 2016. New Microsporidia, Glugea sardinellensis n. sp. (Microsporea, Glugeida) found in Sardinella aurita Valenciennes, 1847, collected off Tunisian coasts. Acta protozoologica 55: 281-290.

Merzoug, D. Z., B. Zitouni, D. I. Gibson, A. Perez-DelOlmo, and A. Kostadinova. 2012. Descriptions of digeneans from Sardina pilchardus (Walbaum) (Clupeidae) off the Algerian coast of the western Mediterranean, with a complete list of its helminth parasites. Systematic parasitology 81:169-186.

Mautner, S. I., K. A. Cook, M. R. Forbes, D. G. McCurdy, and A. M. Dunn. 2007. Evidence for sex ratio distortion by a new Microsporidian parasite of a corophiid amphipod. Parasitology 134: 1567-1573.

Morsy, K., A. R. Bashtar, F. Abdel-Ghaffar, and S. AlQuraishy. 2013. Morphological and phylogenetic description of a new xenoma-inducing microsporidian, Microsporidium aurata nov. sp., parasite of the gilthead seabream Sparus aurata from the Red Sea. Parasitology Research 112: 3905-3915.

Oliva, M. E. 2001. Metazoan parasites of Macruronus magellanicus from southern Chili as biological tags. Fish biology 58: 1617-1624.

Ovcharenko, M., P. Wróblewski, Y. Kvach, and O. Drobiniak. 2017. Study of Loma acerinae (Microsporidia) detected from three Ponto-Caspian gobies (Gobiidae) in Ukraine. Parasitology Research 116: 1453-1462. doi 10.1007/s00436-017-5422-1.

Öztürk, T., and A. Özer. 2016. Digenean parasites of Atlantic horse mackerel (Trachurus trachurus) in the Turkish Black Sea coast. Ege Journal of Fisheries and Aquatic Science 33 (1): 35-40.

Palomera, I., and A. Sabatès. 1990. Co-occurrence of Engraulis encrasicolus and Sardinella aurita eggs and larvae in the Northwestern Mediterranean. Scientia Marina 54: 63-69.

Pérez-del Olmo, A., J. A. Raga, A. Kostadinova, and M. Fernàndez. 2007. Communities in Boops boops (L.)
(Sparidae) after the Prestige oil-spill: Detectable alterations. Marine Pollution Bulletin 54: 266-276.

Phelps, N. B. D., S. K. Mor, A. G. Armien, K. M. Pelican, and S. M. Goyal. 2015. Description of the Microsporidian parasite, Heterosporis sutherlandae n. sp., infecting fish in the Great Lakes region, USA. Plos One 10: $\mathrm{e} 0132027$.

Ramdane, Z., J. P. Trilles, K. Mahé, and R. Amara. 2013. Metazoan ectoparasites of two teleost fish, Boops boops (L.) and Mullus barbatus barbatus L. from Algerian coast: diversity, parasitological index and impact of parasitism. Cybium 37 (1-2): 59-66.

Saadi, N., J. P. Trilles, R. Amara, and Z. Ramdane. 2020. Parasitic nematodes infecting commercial fishes off the coast of Algeria. Zoology and Ecology 30 (1): 74-82. https://doi.org/10.35513/21658005.2020.1.10

Shaw, R. W., M. L. Kent, and M. L. Adamson. 1999. Iodophor treatment is not completely efficacious in preventing Loma salmonae (Microsporidia) transmission in experimentally challenged Chinook salmon, Oncorhynchus tshawytscha (Walbaum). Journal of Fish Diseases 22: 311-312.

Slothouber-Galbreath, J. G. M., J. E. Smith, R. S. Terry, J. J. Becnel, and A. M. Dunn. 2004. Invasion success of fibrillanosema crangonycis, n. sp., n. g.: a novel vertically transmitted Microsporidian parasite from the invasive amphipod host Crangonyx pseudogracilis. International journal for parasitology 34: 235-244.

Smith, J. W. 1983. Anisakis simplex (Rudolphi, 1809, det. Krabbe, 1878) (Nematoda: Ascaridoidea): morphology and morphometry of larvae from euphausiids and fish, and a review of the life-history and ecology. Journal of Helminthology 57: 205-224.

Tantanasi, J., A. Diakou, A. Tamvakis, and I. E. Batjakas. 2012. Anisakis spp. burden in Trachurus trachurus. Helminthology 49 (1): 16-20.

Weissenberg, R. 1968. Intracellular development of the microsporidian Glugea anomala moniez in hypertrophying migratory cells of the fish Gasterosteus aculeatus L., an example of the formation of "xenoma" tumours. Journal of Protozoology 15: 44-57.

Yokoyama, H., S. J. Lee, and A. S. Bell. 2002. Occurrence of a new Microsporidium in the skeletal muscle of the flying fish Cypselurus pinnatibarbatus japonicus (Exocoetidae) from Yakushima, Japan. Folia Parasitologica (Praha) 49 (1): 9-15. 